\title{
Phosphorus Rate in Combination with Cultural Practices Reduces Excessive Growth of Tomato Seedlings in the Float System
}

\author{
James W. Rideout ${ }^{1}$ and Laura F. Overstreet ${ }^{2}$ \\ Mountain Horticultural Crops Research and Extension Center, Department \\ of Soil Science, 455 Research Drive, Fletcher, NC 28732
}

Additional index words. brushing, clipping, ethephon, tobacco float system, Lycopersicon esculentum

\begin{abstract}
Conventional tomato (Lycopersicon esculentum Mill.) seedling production can be labor intensive. The float system of production may be a less labor-intensive alternative. Float system technology is used extensively to produce tobacco seedlings, but is currently used very little for horticultural crop seedlings. Potential advantages of the float system include lowered production cost, more efficient use of water and nutrients, elimination of wetting of plant foliage thus reducing disease, and elimination of nutrient leaching to groundwater below the greenhouse. When grown in float culture using a tobacco nutritional regimen, tomato seedlings produced undesirably long stems. Greenhouse experiments were conducted to identify production practices that may limit this excessive growth. Practices evaluated included two fertilizers with either $2.2 \%$ or $0.87 \%$ P combined with brushing, clipping once, ethephon application, delay of fertilization for $\mathbf{1 0}$ days after seeding, brushing combined with delayed fertilization, and two levels of air movement. Greatest height control was obtained with a combination of practices. Most height control practices, except delayed fertilization (with nor without brushing), were more effective if combined with low $P$ fertilizer. The combination of brushing with delayed fertilization using either fertilizer provided the best height control and the highest quality seedlings. Ethephon and brushing in combination with low $P$ fertilizer were also effective. These experiments show that with use of height-limiting management techniques good quality tomato seedlings can be produced in the float system. The experiment did not address the field performance of the seedlings.
\end{abstract}

Conventional tomato seedling production can be labor-intensive. The float system of production may be a less labor-intensive alternative. Float system technology (Rideout et al., 1994) is used extensively to produce tobacco seedlings in greenhouses, but is used infrequently for horticultural crops. Potential advantages of the float system may include lowered production cost, more efficient use of water and nutrients, reduced disease pressure since plant foliage is not wetted, and elimination of nutrient leaching to groundwater below the greenhouse. Briefly, this system involves constructing shallow wooden frames on the floor of the greenhouse. At the beginning of each season, the frames are lined with polyeth-

Received for publication 21 Mar. 2002. Accepted for publication 9 Dec. 2002. The authors appreciate the excellent technical assistance of Dwayne Tate, April Beddingfield, Beverly Taylor, and the greenhouse staff of the Mountain Horticultural Crops Research Station. This study was supported in part by a grant from the North Carolina Tomato Growers Association. The use of trade names in this publication is solely to ensure accurate description of experimental conditions. No endorsement or criticism of these products or similar products not mentioned is intended.

${ }^{1}$ Assistant Professor, Dept. of Soil Science, North Carolina State Univ.

${ }^{2}$ Graduate Research Assistant, Dept. of Soil Science, North Carolina State Univ. ylene sheeting and filled with nutrient solution formulated with water-soluble, horticulturalgrade fertilizers. Polystyrene flats, filled with peat- and vermiculite-based soil-less media, float on this nutrient solution. All irrigation is by capillary movement of nutrient solution up into the media. The nutrient level of the soil-less media is generally low enough that the majority of the nutrients needed for seedling growth must be provided by the nutrient solution.

When grown in float culture using a tobacco nutritional system (Rideout et al., 1994), tomato seedlings were unsuitable for transplanting due to undesirably long stems, tenderness, and inadequate root systems (J.W. Rideout, unpublished data). High density production of tomato seedlings using conventional systems has also been reported to result in undesirably long stems unless some type of height-controlling cultural practice is used (Garner and Bjorkman, 1996; Liptay, 1985).

Low $\mathrm{P}$ nutrient regimes (P rate limited to less than one-third of the $\mathrm{N}$ rate) are used to assist in controlling tobacco seedling height in the float system (Rideout and Gooden, 1998). In tobacco seedling production, clipping is also used to reduce height and increase seedling uniformity. Clipping involves removal of some of the plant canopy using a raised or suspended lawn mower, while leaving the apical meristem intact (Miner et al., 1983; Rideout et al.,
1994). Brushing, the practice of mechanically bending the seedling stems on a regular basis, has been reported to be an effective means of reducing tomato transplant growth in overheadirrigated production (Garner and Bjorkman, 1996, 1999). Mechanical air movement from plant-level fans has also been reported to reduce tomato seedling height (Liptay, 1992). Application of the growth regulator ethephon has been reported to reduce height and increase stem diameter of tomato (Liptay, 1985) and tobacco (Kasperbauer and Hamilton, 1978).

Greenhouse experiments were conducted to identify production practices that may reduce excessive growth in tomato transplants. Practices evaluated included low P fertilizer, brushing, clipping, growth regulators, delayed fertilization, and air movement. The specific objective of this study was to determine the efficacy of low P fertilizer in combination with growth-limiting cultural practices or a growth regulator in limiting tomato seedling height in the float system.

\section{Materials and Methods}

Experiments were conducted in the summer of 2000 in a polyethylene-covered greenhouse on the Mountain Horticultural Crops Research Station near Fletcher, N.C. Night temperatures ranged between 17 and $22^{\circ} \mathrm{C}$, while day temperatures ranged between 31 and $46^{\circ} \mathrm{C}$ during the course of the experiment. Supplemental lighting was not used.

Practices evaluated included two fertilizers $(15 \mathrm{~N}-2.2 \mathrm{P}-12.5 \mathrm{~K}$ and $15 \mathrm{~N}-0.87 \mathrm{P}-16.6 \mathrm{~K})$ in factorial combination with no additional treatment (control), brushing, clipping, ethephon, delayed fertilization, delayed fertilization with brushing, and two levels of air movement (Table 1). The experimental design was a randomized complete block with treatments replicated three times. Each experimental unit consisted of a single flat containing 128 plants. The experiment was conducted twice. Treatments were identical for both repetitions of the experiment.

Wooden frames $110 \mathrm{~cm}$ long, $75 \mathrm{~cm}$ wide, and $15 \mathrm{~cm}$ deep were constructed and lined with black polyethylene sheeting $(6 \mathrm{mil})$ to form the float tanks. Solution capacity was $76 \mathrm{~L}$. Each frame held three 128 cell (cell size $3.6 \times 3.6$ $\mathrm{cm}$ ) polystyrene Todd flats (Speedling, Sun City, Fla.). Flats were filled with a noncommercial soil-less mixture consisting of 1 peat : 1 vermiculite $(\mathrm{v} / \mathrm{v})$. Other than pulverized dolomitic lime $\left(5.5 \mathrm{~kg} \cdot \mathrm{m}^{-3}\right)$, nutrients were not added to the soil-less mix. Flats were seeded with 'Mountain Supreme' tomato. One seed was placed in each cell, and was covered with $\approx 1 \mathrm{~mm}$ finely ground peat. Flats were floated on the nutrient solutions immediately after all were seeded. All water and nutrients were supplied via capillary movement upward through the media.

With the exception of the delayed fertilization treatments, water-soluble fertilizer was added immediately before flats were seeded. The two $\mathrm{P}$ rates used were $1.5 \mathrm{mg} \cdot \mathrm{L}^{-1}$ (from $15 \mathrm{~N}-0.87 \mathrm{P}-16.6 \mathrm{~K}$ ) and $3.6 \mathrm{mg} \cdot \mathrm{L}^{-1}$ (from $15 \mathrm{~N}-2.2 \mathrm{P}-12.5 \mathrm{~K})$. In all treatments, the initial 
nitrogen rate was $25 \mathrm{mg} \cdot \mathrm{L}^{-1}$. Potassium rates varied due to the differing $\mathrm{K}$ content of the two fertilizers and were not adjusted. One additional application of fertilizer at the initial rate was made halfway through the experiment. In the case of the delayed fertilization treatments, flats floated on plain water until fertilizer was added on day 10 after seeding.

Brushing was accomplished by bending the plants to a $45^{\circ}$ angle five times with a wooden dowel once daily starting on day 10 after seeding. Ethephon (300 $\mathrm{mg} \cdot \mathrm{L}^{-1}$ solution) was applied as a foliar spray (sufficient spray to uniformly wet foliage) on day 13 after seeding. Plants were clipped once on day 16 after seeding and involved removal of leaf tissue from the upper leaves using a raised lawn mower fitted with a high-vacuum blade. The two air movement treatments were accomplished by setting up two fans (Windmere WHV-18/C, $45.7 \mathrm{~cm}$ blade diameter) at plant level. The fans were controlled by a timer and operated at the highest setting for $2 \mathrm{~h}$ each day. Float tanks were set directly in front of the fans (high air) and $2 \mathrm{~m}$ away from the fans (low air). To prevent stand loss due to surface drying of the media, air movement treatments were initiated on day 5 after germination had occurred.

Eight representative seedling shoots per flat were harvested on day 25. At this time, most treatments were of sufficient size for transplanting. Seedling stem height (measured from the stem base to the apical meristem) and stem diameter at the soil line were measured. Seedling tissue was dried in a forced-air oven at $50{ }^{\circ} \mathrm{C}$ for $2 \mathrm{~d}$ before determination of shoot dry weight. Dry matter per unit of plant height was calculated and expressed as mg dry matter per $\mathrm{cm}$ plant. Dry tissue was ground to pass a $1 \mathrm{~mm}$ screen. Tissue $\mathrm{N}$ concentration was determined using a Perkin Elmer 2400 CHN combustion analyzer. Tissue $\mathrm{P}$ concentration was determined by dry-ashing and subsequent analysis using a Perkin Elmer Plasma 2000 inductively coupled plasma spectrometer.
Data from both experiments combined were subjected initially to analysis of variance using a randomized complete-block design with a factorial treatment structure. It was determined that numerous significant $(P \leq 0.05)$ interactions between experiments, fertilizer type, and cultural treatments existed for all measurements. Data were then analyzed for each experiment with each combination of $\mathrm{P}$ rate and cultural practices considered a separate treatment. Mean separation was accomplished using protected least significant difference $(P$ $\leq 0.05$ ). To better understand the nature of the interactions between fertilizer type and the other height-limiting cultural practices, single-degree-of-freedom contrasts were also performed.

\section{Results and Discussion}

Along with reduced $\mathrm{P}$ concentration, the $15 \mathrm{~N}-0.87 \mathrm{P}-16.6 \mathrm{~K}$ fertilizer contained more $\mathrm{K}$ than the $15 \mathrm{~N}-2.2 \mathrm{P}-12.5 \mathrm{~K}$ fertilizer. This confounding of $\mathrm{P}$ rate with $\mathrm{K}$ rate makes it impossible to state that the differences observed due to fertilizer type are solely due to $P$ rate. Increase in nutrient solution $K$ rate from deficient to sufficient has been reported to increase seedling growth of tomato (Al-Karaki, 2000). However, in this study, the use of the higher K 15N-0.87P-16.6K fertilizer resulted in reduced growth. Reducing $\mathrm{P}$ rate has been reported to reduce the seedling growth of tomato (Liptay et al., 1992; Melton and Dufault, 1991), pepper (Bar-Tal et al., 1990), and tobacco (Rideout and Gooden, 1998). It is most likely the growth reductions observed here with the $15 \mathrm{~N}-0.87 \mathrm{P}-16.6 \mathrm{~K}$ fertilizer were due to reduced $\mathrm{P}$ rate, and not increased $\mathrm{K}$ when this material was used at an identical $\mathrm{N}$ rate to the $15 \mathrm{~N}-2.2 \mathrm{P}-12.5 \mathrm{~K}$ fertilizer. Additional evidence of the role of $\mathrm{P}$ in the growth reductions is provided by the significant reduction in tissue $\mathrm{P}$ due to the $15 \mathrm{~N}-0.87 \mathrm{P}-16.6 \mathrm{~K}$ fertilizer regardless of cultural treatment (Table
4, contrast 4) and by the transient appearance of visible $\mathrm{P}$ deficiency symptoms on plants fertilized with $15 \mathrm{~N}-0.87 \mathrm{P}-16.6 \mathrm{~K}$.

\section{Seedling height}

Cultural practices generally reduced height of tomato seedlings grown in the float system with either fertilizer in both experiments (Table 1) (Table 2, contrasts 1-3). Ethephon, delayed fertilization, and delayed fertilization in combination with brushing treatments effectively reduced seedling height, generally with either fertilizer. Brushing and clipping reduced height to a lesser degree. Tomato seedling height was generally reduced by reducing the $P$ concentration of the nutrient solution (Table 1) (Table 2 , contrast 4). High air movement reduced seedling height with both fertilizers, but only directly in front of the fans. In at least one of the two experiments, $15 \mathrm{~N}-0.87 \mathrm{P}-16.6 \mathrm{~K}$ fertilizer further reduced height (compared to $15 \mathrm{~N}-2.2 \mathrm{P}-12.5 \mathrm{~K}$ fertilizer) when combined with other height-limiting cultural practices except for delayed fertilization plus brushing (Table 2, contrasts 5-12). The $15 \mathrm{~N}-0.87 \mathrm{P}-$ $16.6 \mathrm{~K}$ fertilizer improved height reduction in both experiments for the brushing, and air movement treatments. Seedling height with these treatments was generally lower with the lower P fertilizer, while height with the delayed fertilization plus brushing treatment was the same for both fertilizers. The low P control was shorter than the high $\mathrm{P}$ control in both experiments (Table 1). In one of the two experiments, fertilizer did not significantly affect height with the clipping (Expt. 1), ethephon (Expt. 2), and delayed fertilization (Expt. 1) treatments. These observations are based on the lack of a significant contrast (Table 2, contrasts 5-12) where the effect of the fertilizers is examined for each cultural practice.

In Expt. 2, delayed fertilization plus brushing resulted in greater reduction in height than brushing or delayed fertilization alone (Table

Table 1. Cultural practice and P rate effects on tomato seedling height, weight, weight : height ratio, and stem diameter on day 25 after seeding in two greenhouse experiments conducted at the Mountain Horticultural Crops Research Station in 2000. Each combination of cultural practices and P rate is considered a separate treatment due to statistically significant $(P<0.05)$ interactions between $\mathrm{P}$ rate and cultural practices.

\begin{tabular}{|c|c|c|c|c|c|c|c|c|c|}
\hline \multirow{2}{*}{$\begin{array}{l}\mathrm{Ht} \\
\text { control }\end{array}$} & \multirow[b]{2}{*}{ Fertilizer } & \multicolumn{2}{|c|}{$\mathrm{Ht}$} & \multicolumn{2}{|c|}{ Dry wt } & \multicolumn{2}{|c|}{$\mathrm{Wt}: \mathrm{Ht}$} & \multicolumn{2}{|c|}{ Stem diam } \\
\hline & & Expt. 1 & Expt. 2 & Expt. 1 & Expt. 2 & Expt. 1 & Expt. 2 & Expt. 1 & Expt. 2 \\
\hline & & \multicolumn{2}{|c|}{----------cm---------- } & \multicolumn{2}{|c|}{----------mg----------- } & \multicolumn{2}{|c|}{-------mg·cm ${ }^{-1}-------$} & \multicolumn{2}{|c|}{----------mm--------- } \\
\hline Control & $15 \mathrm{~N}-0.87 \mathrm{P}-16.6 \mathrm{~K}$ & 21.7 & 25.1 & 292 & 350 & 13.4 & 14.0 & 2.4 & 3.0 \\
\hline Brushing & $15 \mathrm{~N}-0.87 \mathrm{P}-16.6 \mathrm{~K}$ & 17.4 & 18.7 & 267 & 278 & 15.0 & 14.9 & 2.8 & 2.6 \\
\hline Clipping & $15 \mathrm{~N}-0.87 \mathrm{P}-16.6 \mathrm{~K}$ & 20.0 & 19.3 & 205 & 187 & 10.1 & 9.7 & 2.6 & 2.4 \\
\hline Ethephon & $15 \mathrm{~N}-0.87 \mathrm{P}-16.6 \mathrm{~K}$ & 15.0 & 16.1 & 196 & 302 & 13.0 & 18.9 & 2.4 & 3.6 \\
\hline Delayed fertilization & $15 \mathrm{~N}-0.87 \mathrm{P}-16.6 \mathrm{~K}$ & 20.5 & 19.9 & 271 & 233 & 13.2 & 11.7 & 2.6 & 2.5 \\
\hline Delayed fertilization + brushing & $15 \mathrm{~N}-0.87 \mathrm{P}-16.6 \mathrm{~K}$ & 18.8 & 14.2 & 250 & 192 & 13.3 & 13.5 & 2.9 & 2.1 \\
\hline High air movement & $15 \mathrm{~N}-0.87 \mathrm{P}-16.6 \mathrm{~K}$ & 17.4 & 18.4 & 234 & 272 & 13.4 & 14.8 & 2.6 & 2.5 \\
\hline Low air movement & $15 \mathrm{~N}-0.87 \mathrm{P}-16.6 \mathrm{~K}$ & 21.0 & 19.3 & 242 & 360 & 11.4 & 18.5 & 2.5 & 2.8 \\
\hline Control & $15 \mathrm{~N}-2.2 \mathrm{P}-12.5 \mathrm{~K}$ & 27.6 & 27.4 & 413 & 535 & 14.9 & 19.6 & 2.9 & 3.5 \\
\hline Brushing & $15 \mathrm{~N}-2.2 \mathrm{P}-12.5 \mathrm{~K}$ & 24.2 & 25.1 & 384 & 354 & 15.7 & 14.1 & 2.9 & 3.2 \\
\hline Clipping & $15 \mathrm{~N}-2.2 \mathrm{P}-12.5 \mathrm{~K}$ & 21.2 & 24.5 & 225 & 251 & 10.6 & 10.2 & 2.5 & 2.8 \\
\hline Ethephon & $15 \mathrm{~N}-2.2 \mathrm{P}-12.5 \mathrm{~K}$ & 19.5 & 15.8 & 217 & 372 & 11.1 & 23.7 & 3.0 & 3.8 \\
\hline Delayed fertilization & $15 \mathrm{~N}-2.2 \mathrm{P}-12.5 \mathrm{~K}$ & 21.8 & 15.1 & 263 & 201 & 11.9 & 13.3 & 3.0 & 2.3 \\
\hline Delayed fertilization + brushing & $15 \mathrm{~N}-2.2 \mathrm{P}-12.5 \mathrm{~K}$ & 20.1 & 13.7 & 250 & 161 & 12.4 & 11.8 & 3.0 & 1.9 \\
\hline High air movement & $15 \mathrm{~N}-2.2 \mathrm{P}-12.5 \mathrm{~K}$ & 19.8 & 20.6 & 271 & 327 & 13.7 & 15.7 & 2.9 & 3.0 \\
\hline Low air movement & $15 \mathrm{~N}-2.2 \mathrm{P}-12.5 \mathrm{~K}$ & 24.5 & 27.9 & 304 & 428 & 12.2 & 15.4 & 2.7 & 3.2 \\
\hline $\mathrm{LSD}_{0.05}$ & & 2.4 & 2.1 & 102 & 59 & NS & 2.2 & 0.3 & 0.3 \\
\hline
\end{tabular}

Ns Nonsignificant. 
Table 2. Single-degree-of-freedom contrasts for plant height, dry weight, weight : height ratio, and stem diameter on day 25 after seeding in two greenhouse experiments conducted at the Mountain Horticultural Crops Research Station in 2000.

\begin{tabular}{|c|c|c|c|c|c|c|c|c|}
\hline \multirow[b]{2}{*}{ Contrast } & \multicolumn{2}{|c|}{$\mathrm{Ht}$} & \multicolumn{2}{|c|}{ Dry wt } & \multicolumn{2}{|c|}{$\mathrm{Wt}: \mathrm{Ht}$} & \multicolumn{2}{|c|}{ Stem diam } \\
\hline & Expt. 1 & Expt. 2 & Expt. 1 & Expt. 2 & Expt. 1 & Expt. 2 & Expt. 1 & Expt. 2 \\
\hline 1. Control $(15 \mathrm{~N}-0.87 \mathrm{P}-16.6 \mathrm{~K})$ vs. all other $(15 \mathrm{~N}-0.87 \mathrm{P}-16.6 \mathrm{~K})$ & ** & $* *$ & NS & $* *$ & NS & NS & $* *$ & NS \\
\hline 2. Control $(15 \mathrm{~N}-2.2 \mathrm{P}-12.5 \mathrm{~K})$ vs. all other $(15 \mathrm{~N}-2.2 \mathrm{P}-12.5 \mathrm{~K})$ & $* *$ & $* *$ & $* *$ & $* *$ & NS & $* *$ & $* *$ & NS \\
\hline 3. Control $(15 \mathrm{~N}-2.2 \mathrm{P}-12.5 \mathrm{~K})$ vs. all other (both fertilizers) & $* *$ & $* *$ & $* *$ & $* *$ & NS & $* *$ & $* *$ & NS \\
\hline 4. All $(15 \mathrm{~N}-0.87 \mathrm{P}-16.6 \mathrm{~K})$ vs. all $(15 \mathrm{~N}-2.2 \mathrm{P}-12.5 \mathrm{~K})$ & $* *$ & $* *$ & $*$ & $* *$ & NS & $*$ & $* *$ & $* *$ \\
\hline 5. Control (15N-0.87P-16.6K) vs. control (15N-2.2P-12.5K) & $* *$ & $*$ & $*$ & $* *$ & NS & $* *$ & $* *$ & $*$ \\
\hline 6. Brushing $(15 \mathrm{~N}-0.87 \mathrm{P}-16.6 \mathrm{~K})$ vs. brushing $(15 \mathrm{~N}-2.2 \mathrm{P}-12.5 \mathrm{~K})$ & $* *$ & $* *$ & $*$ & $*$ & NS & NS & $* *$ & NS \\
\hline 7. Clipping (15N-0.87P-16.6K) vs. clipping $(15 \mathrm{~N}-2.2 \mathrm{P}-12.5 \mathrm{~K})$ & NS & $* *$ & NS & $*$ & NS & NS & $*$ & NS \\
\hline 8. Ethephon $(15 \mathrm{~N}-0.87 \mathrm{P}-16.6 \mathrm{~K})$ vs. ethephon $(15 \mathrm{~N}-2.2 \mathrm{P}-12.5 \mathrm{~K})$ & $* *$ & NS & NS & $*$ & NS & $* *$ & NS & $* *$ \\
\hline 9. Delayed fert $(15 \mathrm{~N}-0.87 \mathrm{P}-16.6 \mathrm{~K})$ vs. delayed fert $(15 \mathrm{~N}-2.2 \mathrm{P}-12.5 \mathrm{~K})$ & NS & ** & NS & NS & NS & NS & NS & $*$ \\
\hline 10. Delayed fert + brush $(15 \mathrm{~N}-0.87 \mathrm{P}-16.6 \mathrm{~K})$ vs. delayed fert + brush $(15 \mathrm{~N}-2.2 \mathrm{P}-12.5 \mathrm{~K})$ & NS & NS & NS & NS & NS & NS & NS & NS \\
\hline 11. High air $(15 \mathrm{~N}-0.87 \mathrm{P}-16.6 \mathrm{~K})$ vs. high air $(15 \mathrm{~N}-2.2 \mathrm{P}-12.5 \mathrm{~K})$ & $*$ & $*$ & NS & NS & NS & NS & $* *$ & NS \\
\hline 12. Low air $(15 \mathrm{~N}-0.87 \mathrm{P}-16.6 \mathrm{~K})$ vs. low air $(15 \mathrm{~N}-2.2 \mathrm{P}-12.5 \mathrm{~K})$ & $* *$ & $* *$ & NS & $*$ & NS & $* *$ & $*$ & NS \\
\hline 13. Brushing (both fertilizers) vs. delayed fert + brush (both fertilizers) & NS & $* *$ & $*$ & $* *$ & NS & $*$ & $* *$ & NS \\
\hline 14. Delayed fert (both fertilizers) vs. delayed fert + brush (both fertilizers) & $*$ & $* *$ & NS & NS & NS & NS & $* *$ & NS \\
\hline
\end{tabular}

*Indicates statistical significance at the $5 \%$ level of probability.

** Indicates statistical significance at the $1 \%$ level of probability.

Ns Nonsignificant.

1) (Table 2, contrasts 13 and 14). In Expt. 1, delayed fertilization plus brushing was more effective than delayed fertilization alone (Table 1) (Table 2, contrasts 13 and 14).

Reduction in stem length with low P fertilizer is consistent with other observations with tomato (Liptay et al., 1992; Melton and Dufault, 1991). The ideal practice would be to reduce nutrient solution $\mathrm{P}$ concentration just to the point $\mathrm{P}$ becomes the limiting factor for plant growth, but not to the point where permanent damage is done to future plant growth.

The delayed fertilization treatments were effective in reducing seedling height, regardless of which fertilizer was used. These treatments may have worked by limiting buildup of all nutrients in the soil-less media. When a tray is first floated, nutrient solution moves upward into the relatively dry media. Evaporation of water from the media surface continues to drive the upward movement. This causes an accumulation of nutrients at the media surface. During germination and early growth, there is no plant demand for these nutrients, so they continue to accumulate. Later, as the roots develop, there are high concentrations of available nutrients. Floating the flats on water for the first 10 d eliminated this nutrient buildup. These seedlings were exposed to a much lower media nutrient concentration early in development. Since P rate only influenced height in one experiment for the delayed fertilization treatment and did not influence height in either experiment for the delayed fertilization plus brushing treatment, it is likely that another nutrient was also growth limiting.

Even though the high air treatment significantly reduced seedling height, the air movement treatments were for the most part impractical for commercial use. The height reduction seen from the high air treatment only occurred right in front of the fan. The experimental setup utilized a single fan. The height control effects were not even $1 \mathrm{~m}$ wide, and did not extend more than $2 \mathrm{~m}$ from the fan. The number and size of fans needed to provide this type of air movement on a commercial scale would make this practice economically impractical. In addition, fertilizer salts injury was observed on the seedlings that were shortened

Table 3. Cultural practice and P rate effects on tomato seedling tissue $\mathrm{N}$ and P measured on day 25 after seeding in two greenhouse experiments conducted at the Mountain Horticultural Crops Research Station in 2000. Each combination of cultural practices and $\mathrm{P}$ rate is considered a separate treatment due to statistically significant $(P<0.05)$ interactions between $P$ rate and cultural practices.

\begin{tabular}{|c|c|c|c|c|c|}
\hline \multirow{2}{*}{$\begin{array}{l}\mathrm{Ht} \\
\text { control }\end{array}$} & \multirow[b]{2}{*}{ Fertilizer } & \multicolumn{2}{|c|}{$\mathrm{N}$} & \multicolumn{2}{|c|}{$\mathrm{P}$} \\
\hline & & Expt. 1 & Expt. 2 & Expt. 1 & Expt. 2 \\
\hline Control & $15 \mathrm{~N}-0.87 \mathrm{P}-16.6 \mathrm{~K}$ & 1.95 & 185 & 0.10 & 0.11 \\
\hline Brushing & $15 \mathrm{~N}-0.87 \mathrm{P}-16.6 \mathrm{~K}$ & 1.99 & 2.29 & 0.10 & 0.09 \\
\hline Clipping & $15 \mathrm{~N}-0.87 \mathrm{P}-16.6 \mathrm{~K}$ & 1.94 & 2.46 & 0.11 & 0.12 \\
\hline Ethephon & $15 \mathrm{~N}-0.87 \mathrm{P}-16.6 \mathrm{~K}$ & 2.06 & 3.54 & 0.13 & 0.18 \\
\hline Delayed fertilization & $15 \mathrm{~N}-0.87 \mathrm{P}-16.6 \mathrm{~K}$ & 2.54 & 5.86 & 0.16 & 0.18 \\
\hline Delayed fertilization + brushing & $15 \mathrm{~N}-0.87 \mathrm{P}-16.6 \mathrm{~K}$ & 2.71 & 3.44 & 0.16 & 0.17 \\
\hline High air movement & $15 \mathrm{~N}-0.87 \mathrm{P}-16.6 \mathrm{~K}$ & 2.14 & 2.44 & 0.12 & 0.10 \\
\hline Low air movement & $15 \mathrm{~N}-0.87 \mathrm{P}-16.6 \mathrm{~K}$ & 2.04 & 2.20 & 0.09 & 0.08 \\
\hline Control & $15 \mathrm{~N}-2.2 \mathrm{P}-12.5 \mathrm{~K}$ & 1.77 & 1.92 & 0.18 & 0.14 \\
\hline Brushing & $15 \mathrm{~N}-2.2 \mathrm{P}-12.5 \mathrm{~K}$ & 1.61 & 3.04 & 0.18 & 0.23 \\
\hline Clipping & $15 \mathrm{~N}-2.2 \mathrm{P}-12.5 \mathrm{~K}$ & 1.55 & 1.99 & 0.23 & 0.17 \\
\hline Ethephon & $15 \mathrm{~N}-2.2 \mathrm{P}-12.5 \mathrm{~K}$ & 1.89 & 2.13 & 0.25 & 0.15 \\
\hline Delayed fertilization & $15 \mathrm{~N}-2.2 \mathrm{P}-12.5 \mathrm{~K}$ & 2.67 & 3.22 & 0.32 & 0.14 \\
\hline Delayed fertilization + brushing & $15 \mathrm{~N}-2.2 \mathrm{P}-12.5 \mathrm{~K}$ & 2.98 & 4.08 & 0.36 & 0.16 \\
\hline High air movement & $15 \mathrm{~N}-2.2 \mathrm{P}-12.5 \mathrm{~K}$ & 2.11 & 2.06 & 0.19 & 0.20 \\
\hline Low air movement & $15 \mathrm{~N}-2.2 \mathrm{P}-12.5 \mathrm{~K}$ & 1.60 & 2.08 & 0.17 & 0.16 \\
\hline $\mathrm{LSD}_{0.05}$ & & 0.27 & 0.84 & 0.03 & 0.05 \\
\hline
\end{tabular}

by this practice. Presumably, greater evaporation from the surface of the media increased capillary movement of nutrient solution, and thus increased nutrient accumulation on the media surface.

\section{Seedling dry weight}

All cultural practices, with the exception of brushing in Expt. 1, reduced seedling weight as compared to the high P control (Table 1) (Table 2, contrast 3). Low Pfertilizer generally reduced seedling weight. As is the case with seedling height, low P fertilizer improved the performance of the brushing treatment (Table 2 , contrast 6). Reducing P levels did not affect weight in the clipping and ethephon treatments in Expt. 1 (Table 2, contrasts 7 and 8). In Expt. 2 , reducing P levels decreased weight for clipping and ethephon treatments (Table 1) (Table 2 , contrasts 7 and 8 ). The low $\mathrm{P}$ fertilizer had no effect on the delayed fertilization or delayed fertilization/brushing treatments in either experiment (Table 1) (Table 2, contrasts 9-11).
The general reductions in dry matter accumulation with reduced solution Pconcentration are consistent with published observations with tomato (Melton and Dufault, 1991), tobacco (Rideout and Gooden, 1998) and pepper (BarTal et al., 1990; Dufault and Schultheis, 1994). In most treatments, the reduction in weight was roughly proportional to the reduction in height. The exception to this was the clipping treatment, in which the reduction in weight was a function of both the reduction in height and the removal of leaf material during clipping.

\section{Seedling weight and height ratio}

A high weight per unit length value may indicate a "stocky" seedling, i.e., a seedling that is short with a thick stem and sufficient leaf area. This appears to be the case with ethephon-treated seedlings in Expt. 2 (Table 1). However, the high $\mathrm{P}$ control also had a high weight : height ratio on day 25 , but was too tall to be usable. The lowest values were observed for clipped plants (Table 1). In this 
Table 4. Single-degree-of-freedom contrasts for plant tissue N and P on day 25 after seeding in two greenhouse experiments conducted at the Mountain Horticultural Crops Research Station in 2000.

\begin{tabular}{|c|c|c|c|c|}
\hline \multirow[b]{2}{*}{ Contrast } & \multicolumn{2}{|c|}{$\mathrm{N}$} & \multicolumn{2}{|c|}{$\mathrm{P}$} \\
\hline & Expt. 1 & Expt. 2 & Expt. 1 & Expt. 2 \\
\hline 1. Control $(15 \mathrm{~N}-0.87 \mathrm{P}-16.6 \mathrm{~K})$ vs. all other $(15 \mathrm{~N}-0.87 \mathrm{P}-16.6 \mathrm{~K})$ & $*$ & $* *$ & NS & NS \\
\hline 2. Control $(15 \mathrm{~N}-2.2 \mathrm{P}-12.5 \mathrm{~K})$ vs. all other $(15 \mathrm{~N}-2.2 \mathrm{P}-12.5 \mathrm{~K})$ & $* *$ & $*$ & $* *$ & NS \\
\hline 3. Control $(15 \mathrm{~N}-2.2 \mathrm{P}-12.5 \mathrm{~K})$ vs all other (both fertilizers) & $* *$ & $* *$ & NS & NS \\
\hline 4. All $(15 \mathrm{~N}-0.87 \mathrm{P}-16.6 \mathrm{~K})$ vs. all $(15 \mathrm{~N}-2.2 \mathrm{P}-12.5 \mathrm{~K})$ & $* *$ & $* *$ & $* *$ & $* *$ \\
\hline 5. Control $(15 \mathrm{~N}-0.87 \mathrm{P}-16.6 \mathrm{~K})$ vs. control $(15 \mathrm{~N}-2.2 \mathrm{P}-12.5 \mathrm{~K})$ & NS & NS & $* *$ & NS \\
\hline 6. Brushing $(15 \mathrm{~N}-0.87 \mathrm{P}-16.6 \mathrm{~K})$ vs. brushing $(15 \mathrm{~N}-2.2 \mathrm{P}-12.5 \mathrm{~K})$ & $* *$ & NS & $* *$ & NS \\
\hline 7. Clipping ( $15 \mathrm{~N}-0.87 \mathrm{P}-16.6 \mathrm{~K})$ vs. clipping $(15 \mathrm{~N}-2.2 \mathrm{P}-12.5 \mathrm{~K})$ & $* *$ & NS & $* *$ & NS \\
\hline 8. Ethephon $(15 \mathrm{~N}-0.87 \mathrm{P}-16.6 \mathrm{~K})$ vs. ethephon $(15 \mathrm{~N}-2.2 \mathrm{P}-12.5 \mathrm{~K})$ & NS & $* *$ & $* *$ & NS \\
\hline 9. Delayed fert $(15 \mathrm{~N}-0.87 \mathrm{P}-16.6 \mathrm{~K})$ vs. delayed fert $(15 \mathrm{~N}-2.2 \mathrm{P}-12.5 \mathrm{~K})$ & NS & $* *$ & $* *$ & NS \\
\hline 10. Delayed fert + brush $(15 \mathrm{~N}-0.87 \mathrm{P}-16.6 \mathrm{~K})$ vs. delayed fert + brush $(15 \mathrm{~N}-2.2 \mathrm{P}-12.5 \mathrm{~K})$ & $*$ & NS & $* *$ & NS \\
\hline 11. High air $(15 \mathrm{~N}-0.87 \mathrm{P}-16.6 \mathrm{~K}) \mathrm{vs}$. high air $(15 \mathrm{~N}-2.2 \mathrm{P}-12.5 \mathrm{~K})$ & NS & NS & $* *$ & $* *$ \\
\hline 12. Low air $(15 \mathrm{~N}-0.87 \mathrm{P}-16.6 \mathrm{~K})$ vs. low air $(15 \mathrm{~N}-2.2 \mathrm{P}-12.5 \mathrm{~K})$ & $* *$ & NS & $* *$ & $* *$ \\
\hline 13. Brushing (both fertilizers) vs. delayed fert + brush (both fertilizers) & $* *$ & $* *$ & $* *$ & NS \\
\hline 14. Delayed fert (both fertilizers) vs. delayed fert + brush (both fertilizers) & $*$ & $*$ & NS & NS \\
\hline
\end{tabular}

*Indicates statistical significance at the $5 \%$ level of probability.

** Indicates statistical significance at the $1 \%$ level of probability.

ss Nonsignificant.

case, the low value could be an artifact of tissue removal rather than an indication of the lack of stockiness of the seedlings. There were no significant differences between treatments for weight : height ratio in Expt. 1 (Table 1).

\section{Seedling stem diameter}

Low $\mathrm{P}$ fertilizer reduced stem diameter in all but the delayed fertilization plus brushing treatment in at least one of the two experiments. (Table 1) (Table 2, contrasts 5-12). Only ethephon (Expt. 2) significantly increased stem diameter above that of the respective control with both fertilizers. Ethephon has been reported to increase the stem diameter of tomato (Liptay, 1985) and tobacco (Kasperbauer and Hamilton, 1978). An increase in stem diameter, especially when coupled with a reduction in height, would be a desirable effect of a height control treatment in that it could increase stem strength and transplant toughness. However other than ethephon, the effective height control techniques used here do not also increase stem diameter (Table 1).

\section{Seedling tissue nitrogen and phosphorus}

Fertilizer type did not affect seedling $\mathrm{N}$ when no additional height control was used (Table 4, contrast 5), but significant contrasts for fertilizer type were observed in at least one of the two experiments for all height control treatments except high air movement. For all treatments except delayed fertilization plus brushing, seedling $\mathrm{N}$ concentration was higher with the $15 \mathrm{~N}-0.87 \mathrm{P}-16.6 \mathrm{~K}$ fertilizer in at least on of the two experiments.

Delayed fertilization increased seedling $\mathrm{N}$ concentration over the respective controls for both fertilizers when used either alone or in combination with brushing (Table 3). This would seem to indicate that $\mathrm{N}$ was not the limiting factor in seedling growth in the delayed fertilization treatments. Lowest seedling $\mathrm{N}$ concentrations were observed in the treatments which provided the least growth reduction. The low tissue $\mathrm{N}$ in the spindly plants along with the higher $\mathrm{N}$ concentrations of the shorter, better quality plants suggests that the $\mathrm{N}$ application rate used in this study was adequate where growth is controlled by other practices and was not excessive.

Low Pfertilizer reduced tissue Pconcentration with all height control treatments (Table 3) (Table 4, contrasts 5-12) in Expt. 1, but did not affect seedling $\mathrm{P}$ concentration in Expt. 2 with the exception of the air movement treatment. Clipping, ethephon, and both delayed fertilization treatments greatly increased tissue $\mathrm{P}$ concentration with $15 \mathrm{~N}-2.2 \mathrm{P}-12.5 \mathrm{~K}$ fertilizer in Expt. 1 (Table 3). Presumably this increase is related to the decrease in growth due to these treatments, thus decreasing the dilution effect often found in plants when $\mathrm{P}$ is near deficiency levels.

The lack of differences in seedling P concentration in Expt. 2 suggests that Pmay have been the main growth limiting factor. Although there has not been a critical tissue Plevel established for tomato seedlings, it is likely that several of the treatments resulted in at least transient $\mathrm{P}$ deficiency. Visible P deficiency symptoms (purpling of leaf undersides) were observed on some of the low-P treatments. While a mild P deficiency may be growth limiting, a severe deficiency could damage field performance, as has been reported for tomato (Melton and Dufault, 1991). If P rate is used to manipulate height, care must be taken not to excessively limit $\mathrm{P}$ supply to the point that permanent damage is done to the seedlings.

\section{Conclusions}

Greatest height control was obtained with a combination of practices. Most height control cultural practices were more effective if combined with low $\mathrm{P}$ fertilizer. The exceptions to this were the delayed fertilization treatments, in which case $\mathrm{P}$ rate was irrelevant. The combination of brushing with delayed fertilization provided the best height control and the highest quality seedlings. Ethephon and brushing in combination with low $\mathrm{P}$ fertilizer were also effective.

Initial attempts to grow tomato seedlings in the float system failed due to excessive stem elongation (data not shown). These experiments show that with effective height limiting management techniques, tomato seedlings can be produced in the float system. Delayed fertilization combined with brushing was the most effective practice with either fertilizer and should facilitate production of good quality tomato transplants in the float system. Ethephon application was also effective, but has more potential to adversely effect posttransplant field growth.

What is not known is the effect of these pretransplant cultural and nutritional practices on field performance of the plants. Since pretransplant nutritional (Melton and Dufault, 1991) and cultural (Johjima et al., 1992) practices have been shown to affect post-transplant field performance of tomato, further research is needed to evaluate field performance of low $\mathrm{P}$ fertilizer float-grown tomato seedlings with respect to yield, fruit quality, and earliness.

\section{Literature Cited}

Al-Karaki, Ghazi N. 2000. Growth, sodium, and potassium uptake and translocation in salt stressed tomato. J. Plant Nutr. 23:369-379.

Bar-Tal, A., B. Bar-Yosef, and U. Kafkafi. 1990. Pepper seedling response to transient nitrogen and phosphorus supply. Agron. J. 82:600-606.

Dufault, R.J. and J.R. Schultheis. 1994. Bell pepper seedling growth and yield following pre-transplant nutritional conditioning. HortScience 29: 999-1007.

Garner, L.C. and T. Bjorkman. 1999. Mechanical conditioning of tomato seedlings improves transplant quality without deleterious effects on field performance. HortScience 34:848-851.

Garner, L.C. and T. Bjorkman. 1996. Mechanical conditioning for controlling excessive elongation in tomato transplants: Sensitivity to dose, frequency, and timing of brushing. J. Amer. Soc. Hort. Sci. 121:894-900.

Johjima, T., J.G. Latimer, and H. Wakita. 1992. Brushing influences transplant growth and subsequent yield of four cultivars of tomato and their hybird lines. J. Amer. Soc. Hort. Sci. 117:384-388.

Kasperbauer, M.J. and J.L. Hamilton. 1978. Ethylene 
regulation of tobacco seedling size, floral induction, and subsequent growth and development. Agron. J. 70:363-366.

Liptay, A. 1985. Reduction in spindliness of tomato transplants grown at high densities. Can. J. Plant Sci. 65:797-801.

Liptay, A. 1992. Air circulation in growth chambers stunts tomato seedling growth. Can. J. Plant Sci. 72:1275-1281.

Liptay, A., S. Nicholls, and P. Sikkema. 1992. Op- timal mineral nutrition of tomato transplants in the greenhouse for maximum performance in the field. Acta Hort. 319:489-492.

Melton, R.R. and R.J. Dufault. 1991. Tomato seedling growth, earliness, yield, and quality following pre-transplant nutritional conditioning and low temperatures. J. Amer. Soc. Hort. Sci. 116:421-425.

Miner, G.S., J.S. Cundiff, and J.D. Miles. 1983. Effects of clipping flue-cured tobacco plantbeds on transplant production efficiency and uniformity. Tob. Sci. 27:70-74.

Rideout, J.W. and D.T. Gooden. 1998. Phosphorus nutrition of tobacco seedlings grown in greenhouse float culture. J. Plant Nutr. 21:307-319.

Rideout, J.W., D.T. Gooden, G.D. Christenbury, B.A. Fortnum, D.G. Manley, and R.W. Sutton. 1994. Tobacco transplant production in greenhouses. EC 682, Clemson Univ. Coop. Ext. Serv., Clemson, S.C. 